УДК 316.774:004]:005.3

DOI https://doi.org/10.31470/2518-7600-2019-7-11-25.

NON-STANDARD METHODS OF INFORMATION COLLECTION IN ANALYTICS

\title{
НЕСТАНДАРТНІ МЕТОДИ ЗБОРУ ІНФОРМАЦЇ̈ В АНАЛІТИЦІ
}

\section{НЕСТАНДАРТНЫЕ МЕТОДЫ СБОРА ИНФОРМАЦИИ В АНАЛИТИКЕ}

Володимир Варенко, кандидат педагогічних наук, доцент доцент кафедри документознавстваAssociate Professor of Department of та інформаційно-аналітичної діяльності varenko_v@ukr.net https://orcid.org/0000-0002-65285604

ID: F-6539-2019

Київський національний університет культури і мистецтв, вул. Чигоріна, 14, м. Київ, Україна, 01042

\section{Зоряна Свердлик,}

кандидат історичних наук, доцент кафедри документознавстваAssociate Professor of Department of та інформаційно-аналітичної діяльності

zsverdlyk@gmail.com

https://orcid.org/0000-0002-21040920

ID: B-7629-2019

Київський національний

університет культури і мистецтв, вул. Чигоріна, 14,

м. Київ,

Україна, 01042
Volodymyr Varenko,

Ph.D. in Pedagogical Sciences,

Associate Professor,

Documentation and Information-

Analytical Activity

varenko_v@ukr.net

https://orcid.org/0000-0002-6528-

5604

ID: F-6539-2019

Kyiv National University of Culture and Arts

Chyhorina Str., 14, Kyiv, Ukraine, 01042

\section{Zoriana Sverdlyk,}

Ph.D. in Historycal Sciences,

Scientific Discipline of

Documentation and Information-

Analytical Activity

zsverdlyk@gmail.com

https://orcid.org/0000-0002-2104-

0920

ID: B-7629-2019

Kyiv National University of Culture and Arts

Chyhorina Str., 14, Kyiv, Ukraine, 01042
Scientific Discipline of 


\section{ABSTRACT}

The article analyses the main non-traditional and nonstandard methods of information gathering (in particular, semi-open and closed) in analytics and management. Authors note that modern analysts, being intermediaries between managers/businessmen and investigated objects (processes, phenomena), are forced to use any opportunities to obtain the necessary information to provide the customer with as high quality information product. New conditions force a specialist to seek and use any objective sources of information, and to do this, apply all possible methods and means for quickly obtaining the necessary information that is especially relevant for the business environment. Particular attention is paid to the study of the causes of the emergence of the phenomenon of competitive business intelligence in the analysis. The concept of «new analytics», the emergence of which is conditioned by new challenges and trends in the development of society, is considered, and the most characteristic features of it are determined. Authors separately investigate four layers of information analyst has to work with. The question of organizing information gathering is analyzed. Authors mark that there are many methods/techniques for information collecting, and therefore, it is an overwhelming task to describe them all, so the authors stopped only on non-standard methods for collecting semi-closed and closed information in competitive business intelligence. One of the best methods for collecting implicit information from external sources is telephone conversations. The optimal strategy for collecting information during telephone conversations is presented. One of the easiest ways to conceal for concealed the study of the object the authors named the external observation. Interesting is the method of collecting information so to speak under cover. The authors paid a lot of attention to the method of involving the agent to collect the necessary information. Particular attention in the study deserves the use of technical channels of unauthorized reading of information. It is concluded, that the study of non-standard methods of information gathering only starts to become relevant in domestic science and requires further thorough consideration.

Keywords: analytics, business, method, competitive intelligence, information gathering/collection, closed information. 
Постановка проблеми. «Хто володіє інформацією, той володіє світом!» - цей відомий афоризм сьогодні, як ніколи, звучить актуально. Зрозуміло, для того, щоб володіти інформацією, треба насамперед іiі мати. Сучасному фахівцю 3 інформації, аналітику, управлінцю 3 кожним днем все складніше в інформаційних потоках, що зростають, відшукати потрібну інформацію. Чатує й інша небезпека - необхідно своєчасно зупинитися в пошуках інформації, пам'ятаючи правило, що інформації має бути достатньо для ухвалення єдиного і правильного управлінського рішення.

До 70-90 \% інформації (за різними джерелами) фахівці черпають із відкритих джерел: спеціальна література, неперіодичні і періодичні видання, ЗМI, мережа Інтернет, рекламна продукція, виставки і презентації, ділові комунікації, професійне спілкування тощо. Проте все частіше спеціалістам 3 інформації доводиться звертатися і до так званих напівзакритих, а то й закритих джерел, щоб дістати інформацію, якої бракує. Це, як правило, службова та комерційна інформація, особисті й приватні таємниці, персональні дані та інша інформація. Відповідно до чинного законодавства ми не маємо права отримувати таку інформацію офіційно. Утім, є багато прийомів і методів отримати ii неофіційно, оскільки, як виявляється, вона не така вже й закрита. Ці методи часто на межі порушення законодавства. Незважаючи на це, сьогодні успішно розвивається ціла індустрія здобування такої інформації - конкурентна бізнесрозвідка. Саме іiі нестандартні методи збирання інформації стали предметом нашого дослідження.

Аналіз останніх досліджень і публікацій. Науковий аналіз діяльності фахівців із конкурентної розвідки в бізнесі, в управлінні загалом, перебуває поки що на етапі становлення, оскільки нормативно-правова база, методики і технології їхньої діяльності, функціональні можливості перебувають в активному розвитку. У деяких наукових дослідженнях розглянуто загальні питання збору інформації, подано поради щодо збирання інформації, залишаючи поза увагою поняття конкурентної розвідки (Сурмін, 2006). В інших працях наголошено на появі нового явища - «нової аналітики 
XXI століття», - 3 прикметними особливостями; акцентовано увагу на реальній проблемі отримання достовірної інформації в сьогоденних перевантажених інформаційних потоках (Курносов, 2015). Деякі розвідки (Доронин, 2003; Зеркалов, 2008; Нежданов, 2012) справді зосереджені на конкурентній розвідці в бізнесі, аналітиці, на нестандартних методах i прийомах отримання і збирання інформації, агентурній роботі, використанні технічних засобів. Однак, на думку авторів, не достатньо висвітленими з наукової точки зору залишаються питання щодо нормативно-правового забезпечення діяльності інформаційних агентів, моральний аспект таких дій; до кінця не розкриті механізми та методики збирання інформації 3 напівзакритих і закритих джерел.

Мета статті - узагальнення способів використання нестандартних методів та прийомів збирання інформації в аналітиці, управлінні та бізнесі, зокрема в технологіях конкурентної бізнес-розвідки.

Виклад основного матеріалу дослідження. Ще мудрий китайський стратег і мислитель Сунь-Дзи у знаменитій праці «Мистецтво війни» (Сунь Дзи, 2017) наголошував: «Той, хто знає ворога й себе, ніколи не програє війни...». Про те, що сучасне бізнес-середовище 3 шаленою конкуренцію i прагненням максимального здобуття переваг - це та ж війна, тільки інформаційна, говорити зайве. I виграє, безумовно, той, хто має суттєву перевагу, знає про супротивника / конкурента все і вміло використовує ці знання.

Аналітики, перебуваючи посередниками між управлінцями / бізнесменами і об'єктами (процесами, явищами), що досліджуються, змушені використовувати будьякі можливості отримати необхідну інформацію, щоб надати замовнику якомога більш якісний інформаційний продукт. Де межа, за яку переступати не варто в цьому процесі, - це вже питання моралі і самого дослідника, оскільки питання здобуття конкурентних переваг у конкурентній бізнес-розвідці, як-от збирання інформації, надто конфліктне i, на жаль, майже неврегульоване законодавчо.

Глобальні зміни в суспільстві й економіці, торгівельні війни, кризові явища в бізнес-середовищі дають змогу сьогодні 
дослідникам (Курносов, 2015) твердити про появу «нової аналітики XXI століття», яка повинна адекватно відповісти на актуальні виклики і тенденції. До ознак нової аналітики зараховуємо:

- необхідність опрацьовувати багатовимірні i майже незмірні пласти / потоки формальної інформації;

- розуміти й адекватно оцінювати одразу три пари середовищ: віртуальне і реальне; матеріальне і контекстне; структуроване і хаотичне;

- одночасно сприймати та опрацьовувати раціональну й ірраціональну інформацію;

- поєднувати два інтелекти: людський i штучний (машинний) (Курносов, 2015).

Зрозуміло, інформаційно-аналітична робота в такому, прямо скажемо, агресивному середовищі потребує максимум інтелектуальних і фізичних зусиль, можливостей сучасного інформаційного дослідника. Сьогодні великі потоки неструктурованої, різнопланової інформації нагадують, за визначенням Ю. Курносова, радше «конструктор для автолюбителів, набір запчастин для гри «збери сам», аніж системну інформацію (Курносов, 2015). Перетворити ці розрізнені потоки на доброякісну аналітичну інформацію вкрай складно, а часом i неможливо. Тож реальну об'єктивну інформацію, що адекватно відтворює істинний стан речей із конкретної проблеми, аналітик не завжди може здобути в перевантажених потоках та / чи опрацювати. Такі умови змушують фахівця шукати і використовувати будь-які більшою чи меншою мірою об'єктивні джерела інформації і для цього застосовувати всі можливі методи та засоби для швидкого (оскільки робота аналітика практично завжди відбувається в умовах цейтноту) отримання потрібної інформації. Особливо це актуально для бізнес-середовища.

Сучасному аналітику доводиться мати справу, щонайменше, з чотирма пластами інформації (Сурмін, 2006):

- апріорна інформація, яка містить відомості про об'єкт і предмет дослідження;

- гіпотетична інформація, що зводиться до гіпотез i припущень різного рівня обгрунтованості стосовно досліджуваних властивостей, закономірностей розвитку; 
- методологічна інформація, спрямована на доведення гіпотези, виробленні методики процесу дослідження;

- апостеріорна інформація, отримана як результат аналітичного дослідження даних / відомостей про об’єкт, явище, процес.

На думку Ю. Сурміна, існують три джерела збирання інформації:

- літературні, документальні, в тому числі інтернетресурси;

- сам об'єкт дослідження, акцентований у повному наочному баченні;

- інтелект дослідника або колективний інтелект (Сурмін, 2006).

Згармонізувати інформаційні потоки з цих трьох джерел і створити один ефективний інформаційний продукт не так уже й просто. Отже, уже на початку процесу збирання інформації слід налаштуватися на осмислений, цілісний пошук інформації конкретного змісту 3 випереджувальним характером іï сприйняття і подальшої гармонізації з іншою інформацією.

Методів / прийомів збирання інформації існує надзвичайно багато, тож описувати їх усі виглядає неохопним завданням. Зупинимося на нестандартних методах збирання напівзакритої і закритої інформації в конкурентній бізнесрозвідці.

I. Нежданов наголошує, що перед збиранням інформації, необхідно правильно організувати процес, щоб не траплялося так зване сміття, що відволікає на себе значні ресурси (Нежданов, 2012). Насамперед необхідно скласти опис інформації, що вже $\epsilon$, i швидко іiі систематизувати. Також необхідно чітко сформулювати проблему, визначити, чого саме не вистачає для розв'язання проблеми. I тоді вже з'ясовувати напрями пошуку інформації. В першу чергу, це, звичайно, відкриті джерела: дані про об'єкт з Інтернету, консультації 3 експертами в цій галузі, повідомлення 3MI, дані працівників компанії, щорічні звіти, каталоги компанії, комерційні і фінансові дані, маркетингова і рекламна інформація тощо.

Робота з людьми, на думку I. Нежданова, потребує певної самовіддачі, а відтак має проводитися активно і постійно. 
Працювати з людьми треба так, щоб у них після спілкування залишалося доброзичливе враження і бажання спілкуватися ще (Нежданов, 2012). Перш ніж спілкуватися, необхідно внести у список усіх, хто може знати щось із проблеми.

Телефонна розмова - один із найбільш оптимальних методів для збирання неявної інформації із зовнішніх джерел. Він не потребує багато часу, якщо виявити терпіння i наполегливість, дає можливість поспілкуватися 3 великою кількістю людей у короткий проміжок часу. Спілкуючись телефоном, не варто ставити досить складні запитання, доречно обмежитися кількома простими i доцільними запитаннями. У цьому разі з більшою долею ймовірності можна розраховувати на позитивний результат.

Оптимальна стратегія для збору інформації під час телефонних розмов, на думку К. Митника (Митник, 2004), полягає у наступному:

Насамперед необхідно переговорити 3 відомими вам людьми або з тими, чиї координати є у відкритому доступі.

Отримати всю можливу інформацію 3 місць ї̈ концентрації: довідкові служби, відділ продажу, центри гарантійного обслуговування, відділ зв'язків з громадськістю тощо.

Спробувати переговорити 3 найвищими посадовими особами в організації, оскільки ці люди часто мають бажання спілкуватися.

Управлінці середньої ланки, як правило, неохоче йдуть на контакт, тому 3 ними варто спілкуватися тільки для підтвердження чи спростування вже отриманої раніше інформації.

Дуже важливо під час телефонного спілкування точно фіксувати отримувану інформацію, бажано за допомогою диктофону, оскільки пізніше виникне необхідність і1і класифікувати і порівняти з іншими даними.

Для того, щоб отримати конфіденційну інформацію, К. Митник в праці «Мистецтво обману» (Митник, 2004) наводить кілька варіантів ефективної поведінки за допомогою соціальної інженерії: 
«Обхідний маневр». Перший контакт із секретарем відбувається, щоб отримати контакт з якимось представником адміністрації(головний бухгалтер, начальник відділу кадрів тощо). Зустріч проводиться від імені державних контролюючих органів (податкова, митна, пожежна служба, санепідемстанція тощо). Найкраще - карний розшук, що дає змогу вийти на контакт із будь-яким спеціалістом.

«Терміновість». Трапилось щось таке (трубу прорвало зверху, ДТП, складнощі з родичами чи рідними...), що прямо стосується об'єкта нашого інтересу, а його, на жаль, немає і телефон не відповідає.

«Удаване знайомство». Знайомство відбулося на одному iз заходів (виставка, конференція, банкет...), об'єкт просив надати йому певну інформацію, та його чомусь не виявилося на місці, а номер телефону втрачений.

«Відволікальний маневр». Штучне створення ситуації, коли секретарю не до сторонніх людей (цейтнот) і ви можете попросити терміново з'єднати вас із керівником.

Одним із найпростіших способів прихованого вивчення об’єкта, на думку I. Нежданова, є зовнішнє спостереження. Головна ідея використання цього методу та сама, що й у науці, спостерігати, як поводить себе об'єкт у природних або спеціально створених для нього умовах. Перевага цього методу - побачити дійсну картину життя і функціювання об'єкта, а не спотворену. Якщо штучно створити об'єктові певні умови, можна спостерегти, як він поводитиметься, як зреагує, що робитиме, до кого звернеться, куди піде, тощо(Нежданов, 2012).

Залежно від конкретної проблеми цей метод дає можливість виявити певні особливості поведінки об'єкта:

- контакти об'єкта;

- розпорядок дня;

- реакція на ті чи інші ситуації;

- особливості планування;

- особливості охорони об'єкта...

Під час спостереження за об'єктом важливо бути непоміченим. Маскування має першорядне значення. Залежно від ситуації можливі такі способи: 
- провести рекламну акцію безпосередньо біля об'єкта;

- випити кави у сусідній кав'ярні;

- розпочати «ремонт» автомобіля, що раптово зламався;

- почитати газету на лавці неподалік;

- погуляти із собакою у парку тощо (Нежданов, 2012).

Метод збирання інформації під прикриттям (легендою) проводиться тоді, коли терміново необхідна інформація зсередини об'єкта, а надійних джерел немає. Інформація отримується завдяки прямих контактів із працівниками об'єкта. Найбільш простий спосіб - відвідати офіс компанії, що цікавить аналітика. Легенди можуть бути такими:

- потенційний клієнт;

- журналіст;

- кандидат на вакансію;

- перевіряльник;

- постачальник товарів і послуг (Зеркалов, 2008).

Особливо ефективно прийти в офіс як потенційний кандидат на якусь посаду. Звичайно, для такого відвідування необхідно знайти причину, зокрема оголошення про пошук працівників. Потрапивши в офіс, можна отримати багато інформації:

- скільки людей працює;

- настільки активно працюють;

- як ставляться до роботи;

- в якому стані офіс, меблі, оргтехніка;

- як часто бувають телефонні дзвінки;

- чи багато клієнтів тощо.

У спілкуванні з працівником можна дізнатися про рівень зарплати, вчасність виплат, політику керівництва стосовно персоналу, загальний стан підприємства...

Метод залучення агентури вважається в конкурентній бізнес-розвідці найбільш дієвим способом отримання точної і своєчасної інформації (Землянов, 2007; Ронин, 2008). Саме агенти, якщо правильно їх залучити, можуть надати інформацію про заплановані заходи ще на етапі їх планування i розробляння. Агенти бувають різні: від організаціїконкурента, заслані ззовні, разові, використовувані «наосліп», агенти-дезінформатори тощо. Вибираючи агента, звертають 
увагу на особливості людини, що вирізняє іiі з-поміж інших. Особливу увагу на недоліки, політичні погляді, захоплення, національні особливості, фінансовий стан, релігійність, зв'язки тощо. На цьому етапі можливо окреслити основні сценарії вербування агента, які можливо здійснити, використовуючи переконання кандидата в агенти, компромат, почуття або акцентуючи на фінансовій вигоді (Зеркалов, 2008). Вербуючи можливого майбутнього агента, необхідно звернути увагу, щоб у нього не було очевидних зв'язків і з замовником, і 3 конкурентами.

Ще одним способом отримання інформації $\epsilon$ використання технічних каналів несанкціонованого зчитування інформації. Сьогодні в бізнес-розвідці цей метод використовують нечасто. Матеріал подаємо за I. Неждановим (Нежданов, 2012):

1. Використання мікрофона чи диктофона. Щоб дізнатися зміст розмови, достатньо встановити у потрібному місці мікрофон чи диктофон, звичайно замаскувавши його. Метод простий і доступний будь-якій людині. Замість диктофона можна залишити увімкненим із відповідною функцією комп'ютер, телефон.

2. Радіозакладки (жучки, радіомікрофони і т. д.) - досить простий і ефективний спосіб отримувати інформацію. Їхня перевага - компактність і автономність роботи. Недоліки: потрібен доступ в приміщення i відкритість каналу передавання інформації (можливість виявити технічними засобами).

3. Стетоскопічний спосіб. Полягає в прослуховуванні сусідньої кімнати (приміщення) через стіни за допомогою спеціального приладу - стетоскопа, що складається з чуттєвого елемента і підсилювача. Пристрій дає можливість зрозуміти зміст розмови на відстані і не потребує проникнення в приміщення.

4. Лазерний випромінювач. Спрямовується на скло досліджуваного приміщення, зворотний промінь подається на приймач. Звукові хвилі в приміщенні діють на скло і, таким чином, відбувається передавання інформації. 
5. Радіоперехоплення - один із найпростіших i найбезпечніших способів отримання інформації, відомий здавна. Непотрібне проникнення в приміщення, достатньо розташуватися неподалік з приймачем.

6. Аналіз телефонних контактів. Здійснюється на основі інформації, отриманої від оператора зв’язку за певний період часу. За допомогою цих даних можна отримати інформацію про те, з ким в об'єкта найбільш часті контакти, частоту зв'язку 3 певними особами, чи контактував об'єкт з відомими замовнику особами, коли і як часто та інші важливі дані.

7. Прослуховування мобільного телефону. Доступ до змісту переговорів відбувається двома шляхами: оператором мобільного зв'язку і радіоперехопленням. В першому випадку підключення відбувається до апаратури оператора, у другому 3 допомогою приймача (до 500 м) приймаються всі вхідні і вихідні сигнали.

8. Прослуховування стаціонарного телефону. Зі стаціонарного телефону можливостей зчитування (зняття) інформації дещо більше: апаратура оператора зв’язку (ATC), телефонна лінія оператора, телефонна лінія абонента, сам телефонний апарат абонента.

Звичайно, розглянутими методами i прийомами отримання конкурентної інформації бізнес-аналітика не вичерпується. Із розвитком науково-технічного прогресу коло таких методів і способів буде тільки розширюватись.

Висновки та перспективні подальших розвідок у даному напрямку. Таким чином, розглянувши використання нестандартних методів і прийомів у конкурентній розвідці бізнес-аналітики, можемо сказати, що насамперед потребує унормування нормативно-правова база реалізації таких методик збору інформації. Безумовно, ця тема тільки починає набувати актуальності у вітчизняній науці та потребує всебічного розгляду. Проблемним моментом є те, що значна частина описаних методів, зокрема збирання закритої, конфіденційної, бізнес-інформації, уже зараз суперечить чинному законодавству або ж перебуває на межі його порушення. Проте оскільки, таке явище існує, ба більше, активно розвивається, ми не змогли його обійти і зробили 
спробу принаймні окреслити проблему. Перспективними вважаємо подальші дослідження щодо удосконалення нормативно-правової бази зазначеної діяльності, використання новітніх методик збирання інформації, а також висвітлення морального аспекту таких дій.

\section{ДЖЕРЕЛА ТА ЛІТЕРАТУРА}

1. Доронин А. И. Бизнес-разведка. 2-е изд., перераб. и доп. Москва: Ось-89, 2003. 384 с.

2. Землянов В. М., Тарас А. Е. Агентура в разведке и контрразведке. Минск: Харвест, 2007. 431 с.

3. Зеркалов Д. В. Разведка: хрестоматия. Киев: Науковий світ, 2008. 190 с.

4. Курносов Ю. В. Аналитика как интеллектуальное оружие. 2-е изд., стер. Москва: Ритм, 2015. 613 с.

5. Митник К. Искусство обмана. Москва: Компания АйТи, 2004. $416 \mathrm{c}$.

6. Нежданов И. Ю. Технологии разведки для бизнеса. Москва: Ось-89, 2012. 400 с.

7. Сунь Дзи. Мистецтво війни. Львів: Видавництво Старого Лева, 2017. 110 с.

8. Сурмін Ю. П. Майстерня вченого: підручник для науковця. Київ: Навчально-методичний центр «Консорціум 3 удосконалення менеджмент-освіти в Україні», 2006. 302 с.

9. Ронин Роман. Это тонкое дело - разведка. Москва: Гринлайт, 2008. 352 с.

10. Ярочкин В. И., Бузанова Я. В. Корпоративная разведка. Москва: Ось-89, 2005. 304 с.

\section{REFERENCES}

1. Doronin, A. (2003). Biznes-razvedka [Business intelligence]. Moscow: Os-89. 384 [in Russ.].

2. Zemlyanov, V. \& Taras, A. (2007). Agentura $v$ razvedke $i$ kontrrazvedke [Agents in intelligence and counterintelligence]. Minsk: Harvest. 431 [in Russ.].

3. Zerkalov, D. V. (2008). Razvedka [Intelligence]. Kiev: Naukoviy svit. 190 [in Russ.].

4. Kurnosov, Yu. (2015). Analitika kak intellektualnoye oruzhiye [Analytics as an intellectual weapon]. Moscow: Ritm. 613 [in Russ.]. 
5. Mitnik, Kevin. (2004). Iskusstvo obmana [Art of deception]. Moscow: Kompaniya AyTi. 416 [in Russ.].

6. Nezhdanov, I. (2012). Tekhnologii razvedki dlya biznesa [Intelligence technologies for business]. Moscow: Os-89. 400 [in Russ.].

7. Sun, Dzy (2017). Mystetstvo viiny [Art of War]. Lviv: Vydavnytstvo Staroho Leva. 110 [in Ukr.].

8. Surmin, Yu. (2006). Maisternia vchenoho [Workroom of the scientist]. Kyiv: Educational and Methodological Center «Konsorcium z udoskonalennya menedzhment-osvity v Ukrayini». 302 [in Ukr.].

9. Ronin, R. (2008). Eto tonkoye delo - razvedka [This is a delicate matter - intelligence]. Moscow: Grinlayt. 352 [in Russ.].

10. Yarochkin, V. \& Buzanova Ya. (2005). Korporativnaya razvedka [Corporate intelligence]. Moscow: Os-89. 304 [in Russ.].

\section{АНОТАЦІЯ}

У статті проаналізовано основні нетрадииійні та нестандартні методи збору інформачії (зокрема, напіввідкритої $і$ закритої) в аналітиці й управлінні. Зауважено, що сучасні аналітики, перебуваючи посередниками між управліниями / бізнесменами $і$ досліджуваними об'єктами (процесами, явищами), змушені використовувати будь-які можливості отримати необхідну інформащію, щоб надати замовнику якомога якісніший інформаційний продукт. Нові умови змушують фахівия шукати і використовувати будь-які об 'єктивні джерела інформації $і$ для иъього застосовувати всі можсливі методи й засоби для швидкого здобуття потрібної інформачїі, що особливо актуально для бізнес-середовища. Особливу увагу зосереджено на дослідженні причин появи явища конкурентної бізнес-розвідки в аналітиці. Розглянуто поняття «нова аналітика», поява якої зумовлена новими викликали і тенденціяли розвитку суспільства, та визначено найхарактерніші ї̈ ознаки. Окремо досліджено чотири пласти інформації, з якими доводиться праџювати аналітику. Проаналізовано питання про організачію збору інформаџії. Зауважено, що методів/прийомів збору інформачії існує чимало, а отже, описати їх всі-непосильне завдання, тому 
автори зупинилися лише на нестандартних методах збору напівзакритої $i$ закритої інформації у конкурентній бізнесрозвідиі. Одним із найбільш найкрашчих методів для збору неявної інформачії із зовнішніх джерел є телефонні розмови. Подано оптимальну стратегію для збору інформації під час телефонних розмов. Одним із найпростіших способів прихованого вивчення об'єкта автори називають зовнішнє спостереження. Цікавим є метод збору інформації так би мовити під прикриттям. Чимало уваги автори приділили методу залучення агентури до збирання потрібної інформації. Особливої уваги в дослідженні заслуговує використання технічних каналів несанкиіонованого зчитування інформації. Зроблено висновок, щуо дослідження нестандартних методів збору інформації тільки починає набувати актуальності у вітчизняній науці та потребує подальшого всебічного розгляду.

Ключові слова: аналітика, бізнес, метод, конкурентна розвідка, збирання інформаџї, закрита інформація.

\section{АННОТАЦИЯ}

В статье проанализированы основные нетрадиционные и нестандартные методы сбора информации (в частности, полуоткрытой и закрытой) в аналитике и управлении. Замечено, что современные аналитики, находясь посредниками между управленцами / бизнесменами и исследуемыми объектами (процессами, явлениями), вынуждены использовать любые возможности получить необходимую информацию, чтобь предоставить заказчику как максимально качественныц информационный продукт. Новые условия вынуждают специилиста искать и использовать любые объективнье источники информации и для этого применять все возможные методы и средства, что особенно актуально для бизнес-средыл. Особое внимание сосредоточено на исследовании причин появления в аналитике конкурентной бизнес-разведки. Рассмотрень понятия «новая аналитика», появление которой обусловлено новыми вызовами и тенденциями развития общества, и определены наиболее характерные ее признаки. Отдельно исследованы четыре пласты информации, с которыми приходится работать 
аналитику. Рассмотрен вопрос об организачии сбора информации. Замечено, что методов / приемов сбора информации существует немало, и следовательно, описать их все - непосильная задача, поэтому авторы остановились лишь на нестандартных методах сбора полузакрытой и закрытой информации в конкурентной бизнес-разведке. Одним из самых лучших методов для сбора информации из внешних источников являются телефонные разговоры. Наведена оптимальная стратегия для сбора информации во время телефонных разговоров. Одним из самых простых способов скрытого изучения объекта авторы называют наружное наблюдение. Интересен метод сбора информации под прикрытием. Немало внимания авторы уделили методу привлечения агентуры к сбору нужной информации. Особое внимание в исследовании заслуживает использование технических каналов несанкционированного считывания информации. Сделан вывод, что исследования нестандартных методов сбора информации только начинает приобретать актуальность в отечественной науке и требует дальнейшего всестороннего рассмотрения.

Ключевые слова: аналитика, бизнес, метод, конкурентная разведка, сбор информации, закрытая информация. 